\title{
Ethical Leadership and Its Relationship with Sales Force Performance Mediated by Trust of Sales Employees on their Leaders
}

\author{
Gawai MILIND $^{\star}$, Iyer RADHA ${ }^{\star \star}$, Kedia NEEL ${ }^{\star \star \star}$, Bhakkad PRATIK ${ }^{\star \star \star \star}$
}

\begin{tabular}{l} 
A R T I C L E I N F O \\
\hline Article history: \\
Accepted April 2019 \\
Available online April 2019 \\
\hline JEL Classification \\
M10, M31 \\
Keywords: \\
Ethical leadership, Sales, trust, \\
performance, organization, sales \\
force
\end{tabular}

\section{Introduction}

Businesses today operate in highly competitive environments, where maintaining profitability is becoming increasingly difficult owing to reducing barriers for competitors to emulate strategies. The sales force is one of the differentiating strategic components for generating persistent sales revenues for an organization, enabling sustainable profit through continuous cash inflows. In today's competitive markets, sales function is still considered as an important factor for success for most organizations (Ingram, Schwepker, \& Hutson,1992) and one of the important considerations faced by the businesses is to manage and control their sales force and increase their performance outcomes (Humphreys, 2002; Singh, Koshy, \& Ramendra, 2010). Performance can be considered to be driven by the degree to which the employees find the organization's values in-line with their own values. An earlier study has shown that one's personal values get aligned with the organization's values when the ethical standards of behaviour are set right by the management and 'ethics has largely to do with management' (Paine, 1994).

Francis (Francis, 2000) has identified the differences between morals, ethics, and values: The terms ethics and morals are many a times used indistinguishably, although one can determine the differences. Generally, 'morals' refers to the standards which are generally considered acceptable by the community, mostly in a form that is clearly unarticulated, whereas, 'Ethics' refers to explicitly defined codes of conduct and the value systems. Ethics is a well-defined form of behavior and attitude intended to produce desired results and acts in resonance with particular values. There are two forms of values: admirable values (like success or wealth) and there are some other values like fairness or honesty (Francis, 2000).

Extensive research has been previously conducted to identify the drivers for sales performance. The starting point to this study can be traced back to the categorization scheme of sales performance antecedents developed by Walker, Churchill and Ford in 1977 (Verbeke, Dietz, \& Verwaal, 2010). Subsequently, it was found that marginal variance in sales performance can be attributed to six categories of predictors: aptitude, skill levels, role perceptions, motivation, personal characteristics and environmental/organizational variables. The three moderating variables taken into consideration were product type, customer type and type of dependent measure used (Churchill, Gilbert, Ford, Hartley, \& Walker, 1985).

\section{Antecedents to sales performance}

There are many antecedents to sales performance. Following are some of the major antecedents which affect the sales performance directly or indirectly. Some of the sales force scholars have proved that the sales force performance and role perceptions (such as role conflict and role ambiguity) have inverted $U$

\footnotetext{
${ }^{\star},{ }^{\star \star}$ K.J. Somaiya Institute of Management \& Research, India. E-mail address: milind.gawai@somaiya.edu (Corresponding author).
} 
relationship between the performance and actual felt stress (Onyemah, 2008). Role overload as a construct is seldom used in research about salespeople. It is described as a situation when the time available is far less than the amount of work to be performed, which therefore leads to uncertain performance (Dellagi, 2015). Many studies have been undertaken to ascertain the effects of burnout on the sales employee performance. Regression analysis to evaluate the impact of burnout on sales performance and relationship between satisfaction, intrinsic motivation, their intentions to leave the organization, role ambiguity, role conflict, performance and burnout of the sales force working in sales department. The result indicates that 'burnout' had a substantial positive impact on the sales force performance. Performance, satisfaction and intention to leave the organization are positively correlated to each other; whereas, these variables had negative relationship with role conflict, role ambiguity and burnout of the sales force (Wali, Saqib, \& Hummayoun , 2015).

Also, it has been prove that the product types the sales force sells increases the relationship with key determinants. It has been proven that a salesperson's aptitude has a stronger impact when selling products than selling the services (Emmanuel, 2013). Also, dispositional traits impact the job satisfaction which then affects the performance of an employee (Sarwar \& Hasan, 2015). It has been clearly proven that personal/ individual factors influence how sales force performs (Wang, 2000). Some of persons' identities are more selfrelevant than others. A major identity of being a salesperson can possibly encourage sales employees to actively find out resources that will help them to become better salespersons and to spend more efforts in performing of their jobs (Fish, Wittmann, \& Arnett, 1989). Some research shows that cognitive style and the adaptiveness of the sales force is an antecedent to self-perceived sales performance (McIntyre, Claxton, Anselmi, \& Wheatley, 2000).

There are also certain factors such as micro selling interpersonal skills which directly influence the sales performance (McIntyre, Claxton, Anselmi, \& Wheatley,2000). The salesperson's degree of adaptiveness in the organization and motivation level has been demonstrated as a significant predictor of sales force performance (Churchill, Gilbert, Ford, Hartley, \& Walker, 1985). Also, macro selling related knowledge which relates to behavior of salespeople in giving information about the specifications, design, functions and applications of products and services impact the performance of the sales force (McIntyre, Claxton, Anselmi, \& Wheatley, 2010).

Alignment of salespersons to their goals leads to better sales performance (Chakrabarti, Bradley, Leyland, Pierre , \& Lien , 2014). Various studies have shown that work engagement directly influences bothin-role as well as extra role sales performance, showing that engaged workers are more likely to perform well in on-job related tasks (in-role performance) and also extra- role performance (Jackson, 2014). It has been proven that personal factors (biographical) such as age, race, sex and educationalso affect the sales performance.

Organization's environment may also have an effect on how the sales force handles general successes and goal attainment. In organizations where environment is highly competitive, salespeople's self-set goals are affected (Emmanuel, 2013). A research study by (Brown, Cron, \& Slocum, 1998) found that hiring more competitive sales persons and promoting more competitive environment would lead to more effective goal setting and increased sales performance.Also, there are many internal environments (such as organization culture, entity size, etc.) as well as external environment (such as sector, economic condition, customers, type of market, etc.) which indirectly impacts the sales force performance (Dragnić, 2014). Many research studies have been done which show that sales persons today are more and more involved in jobs that require supervisory leadership skills and how these skills impact the performance of sales force have been discussed (Flaherty, Mowen, Brown, \& Marshall, 2009).

Also, there are some other antecedents which indirectly affect the sales performance. First being the work effort by the sales force. Effort can be considered a mediating factor by which motivation is converted into accomplished work (Steven \& Peterson, 1994). Although not much importance has been given to effort as a direct antecedent of sales performance, some authors have obtained results which show that the work effort has strong evidence as a direct antecedent to sales performance (Bartkus, Kenneth, Peterson, \& Danny, 1989).

Yet another antecedent which indirectly affects the sales performance is selling experience. The salesperson's sales experience is found to be another important predictor of sales performance (Bartkus, Kenneth, Peterson, \& Danny, 1989; Behrman, Perrault, \& Douglas, 1984; Kerr \& Jermier, 1978; Walker, Orville , Gilbert, \& Ford, 1977). Experience leads to higher levels of sales-related knowledge and skills and it has been noted to influence a number of important variables such as motivation, job skills, role perceptions, customer orientation and finally, performance (Ingram, Thomas, \& Bellenger,1983; O'hara, Brandley, Boles, \& Johston, 1991; Walker, Orville, Churchill, \& ford, 1975). Experienced salespeople have better knowledge of their customers, jobs and the company policies (Churchill, Gilbert, Ford, \& Walker, 1976).

The next antecedent which indirectly affects the sales performance is creativity. Salesperson creativity has received virtually no attention in the past. There have only been speculations about the effect of creativity on sales performance though lot of anecdotal evidence is available to substantiate the same. It is suggested that the salesperson's creativity can possibly improve his/her job performance for at least three 
reasons. First, the efficiency and effectiveness of performing many job activities may increase when the salesperson is able to creatively utilize available resources and find new and better ways of getting the work done. Second, creative identification of prospective customers and recognizing their problems can probably lead to more successful development of new sales accounts. Third, creative solutions to customer problems tend to delight the customer and increase customer satisfaction, thereby increasing retention of customer and improving the word-of-mouth referral. Therefore, it is suggested that creativity makes a strong contribution to performance beyond the effects of experience and effort (Wang, 2000).

Evidence from prior research reveals that the level of employee perceptions about work roles, skills, motivation, etc., can be changed by providing more training and experience or by formulating effective policies for the organization have more impact on employee performance than physical/personal traits (Nema \& Sethia, 2015). Though environmental/organizational variables constitute a wide variety of factors viz. supervisory leadership and environment, both external and internal (Verbeke, Dietz, \& Verwaal, 2010), which in turn again consist of a number of sub-factors, organizations will be able to take concrete policy decisions if the effects of each sub-factor on sales performance is well determined. Managing environment is generally beyond the scope of any organization. However, organizations can manage the type of leaders they employ, to achieve higher employee performance. Various researches have been conducted to analyze the correlation between ethical leadership and sales performance (Hayati, Atefi, \& Aheame, 2018). A study by (Aydin \& Kaya, 2016) shows that authentic and ethical leadership has a strong impact on sales people performance.

Fig. 1. Conceptual model

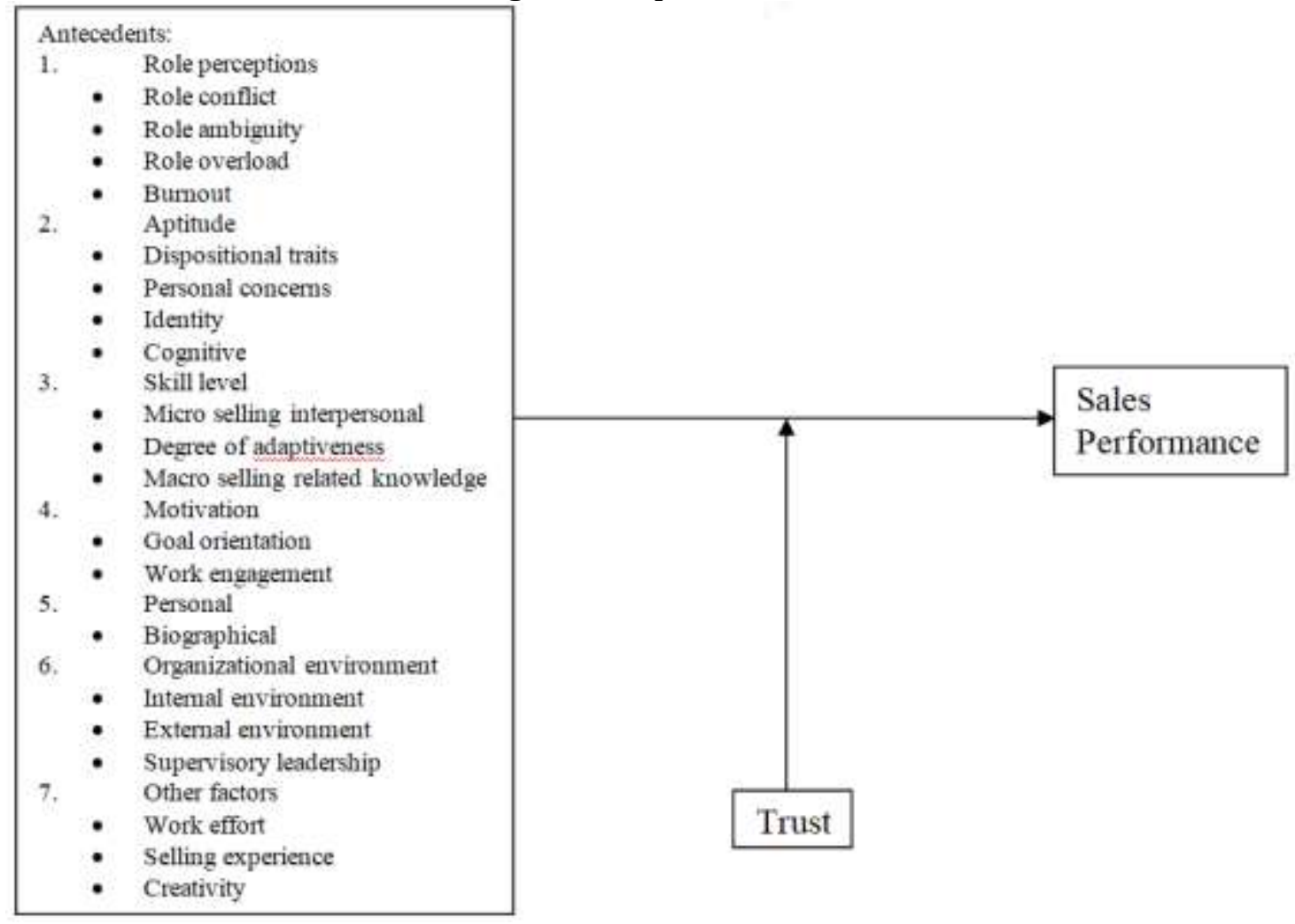

Thus, this research focuses on a detailed study of ethical leadership adopted by the organization's management as the antecedent factor and its relationship with the extent to which their followers will trust them, leading to varied levels of sales force performance outputs, as there is limited literature in this area.

This opens new avenues that the managers could take into consideration regarding their leadership behavior. Which therefore influence the attitudes of the employees towards their job by having a significant impact on the organizations' sales performance (Hafeez \& Hasnain, 2012).

There have been studies previously done on ethical leadership and individual work performance. Also, there have been some studies highlighting the positive impact of employee trust in their leaders on their work outcomes. But, limited studies have focused on all the three variables, viz. ethical leadership, trust and sales performance together. This research will enable the researchers to project certain findings and recommendations for the practicing managers, enabling them to lay down concrete policies to promote ethical behavior at each level of management resulting in long term increased sales revenues for the organization. 


\section{Literature review Ethical leadership}

Ethical leadership can be defined as 'the demonstration of normatively appropriate conduct through interpersonal relationship and personal actions, and the promotion of such conduct to the followers through decision making, two-way communication and reinforcement' (Brown, Linda, \& David, 2005). Ethical behavior is a process which affects the entire community that deals with the moral behaviour of individuals, established on well-expressed and established standards of individual values (Bishop, 2013). Due to this, the workplace ethics becomes an inseparable part of nurturing teamwork and increased productivity among the employees (Suhonen, Stolt, Virtanen, \& Leino-Kilpi, 2011). Ethical leadership is considered to be extremely important due to the effect leaders can have on the organization and eventually, on the organization's performance (Aronson, 2001; Kanungo, 2001; Trevino, 2003). An ethical leader is "a person who lives up to his/her principles of conduct that are crucial for him/her". It is said that, to be an ethical leader, you need to stick to a universally accepted standard of moral behaviour (Thomas, 2001). An effective and ethical leader has characteristics such as: dignity and respectfulness, serving others, community building, justice and honesty (Juneja, 2010). Many researches show that ethical leadership can motivate the employees and is positively correlated with favourable employees' outcomes which includes behaviour and attitude and is found to be effective in reducing the undesirable outcomes like employee turnover, job dissatisfaction, etc. (Bedi, Alpaslan, \& Green, 2016; Chen \& Hou, 2016).

In the recent times, the organizations are showing increasing concern about the ethical behaviour of their employees, which is apparent from the increasing number of firms including a dedicated section for the 'ethical behaviour guidelines' in their employee handbooks.

The ethical values which constitute the corporate governance standards are: honesty, fairness and balance, accountability, transparency, good-will and dignity. The ethical behaviour standards should be clearly specified by the organizations which are expected out of the key executives and company directors to encourage the adherence to those standards (Armstrong \& Francis, 2008).

\section{Trust}

Trust can be defined as 'the willingness to be vulnerable based upon positive expectations of the behaviour or intentions of another party'. Employee's trust in leader is defined as 'a psychological state comprising the intention to accept vulnerability based upon positive expectations of the behaviour or intentions of another party' (Rousseau D. M., Sitkin, Burt, \& Camerer, 1998). It also concerns with the degree of confidence a person has in other persons, to behave in fair or predictable manner (Luhmann, 1982) i.e., employee trust in their leaders can be regarded as the followers' faith in the actions and also confidence in the intentions of their leaders (Cook \& Wall, 1980).

Three different views exist in framing the definitions of trust: The first view sees trust as a personality trait or generally expected behaviour (Rotter, 1967), the second view treats trust as an attitude towards others or the perspective that others will possibly behave in a way that is favourable to others (Driscoll, 1978) and the third view considers it from the view of risking behaviours (Schurr \& Ozanne, 1985), which shows the readiness to accept the possibility of vulnerability in any transaction (Dwyer \& Lagace, 1986). dimensions:

The construct of trust in leaders can essentially be considered to be measured by following four

(1) competence: The level to which the person shows a group of characteristics, competencies, and skills that permit them to have influence in a particular domain;

(2) integrity: The level to which the person's actions match their words and is seen as honourable;

(3) benevolence: The level to which the person is seen to be truly concerned and caring;

(4) predictability: The level to which the persons' behaviour is perceived to be consistent over time (Adams, 2008).

\section{Sales performance}

Selling can be considered as an act of product and service performance which provides return on investments, benefits, profits and sustains and improves the existing operations of the business (Kukic, et al., 2007). Performance can be stated as an assessment of the salesperson's behaviour in comparison to that behaviour's contribution to the objectives of organization (Churchill, Ford, Hartley, \& Walker, 1985). Sales performance can be defined as 'the quality and quantity of sales closed at a particular time'. Salesmen who have the right personality traits are the ones who are able to take the potential customer through the process of selling which consists of: prospecting the potential leads, pre-approach preparations, approaching the customer, presenting the sales pitch, closing the deal and follow-up post sales (Bandura, 2003; Locke, 2002; Luthans, 2002). The sales force plays a key role in both- the formulation as well as the implementation of core strategic plans (Piercy \& Lane, 2005). 
Salesperson's performance can be of two types: first being behaviour performance and other being outcome performance. Sales unit effectiveness and salesperson outcome performance though independent but are also related (Baldauf, Cravens, \& Grant, 2002; Piercy, Low, \& Cravens, 2011). Favourable results that are accomplished by salespersons lead to effectiveness of organizations. Sales outcome performance comprises of the final results (such as new accounts, market-share and sales) that sales force produces (Anderson \& Oliver, 1987). In absence of the sales force, sales organization's effectiveness cannot be possibly accomplished, since it is the sales force which directly deals with the customers and also generates the major revenue for the organization (Fatima \& Zoha, 2018). Sales management's behaviour, sales force outcome performance, contention with sales unit design, and compensation control are expected to impact/affect the effectiveness of the sales unit (Cravens, Piercy, \& Low, 2006).

Leadership in a sales perspective is far more than just verbally reacting to what a salesperson has done. To be an effective and believable leader, a sales manager must set an ideal example through their own behavior, which makes him/her the role model to followers (Gregory \& Rich, 1997).

Though much of the past research has focussed on the relationship of ethical leadership on employees' work in-role performance, little empirical research has been performed to understand the specific relation with sales force performance. Trust of the employees on their leaders can be an important motivating factor leading to an increased level of sales output for the organization. This paper intends to thus understand if trust has a mediating relationship with the role of ethical leadership and sales performance.

\section{Research model and hypothesis development}

In the following section, we theorize the hypotheses that we intend to derive for addressing the research questions. Fig.6.1 and Fig.6.2 represent the proposed models for study.

\section{Ethical leadership and level of employee trust on their leaders}

Many studies of the past are centred around the correlation between ethical leadership and trust that employees have on their leaders. Various constructs of ethical leadership like integrity, accountability and ethical awareness are found to have a positive relation with employee trust on their leaders (Rahim \& Salleh, 2010). An employee will trust a leader if he shows certain desirable characteristics in his behavior like honesty, kindness, generosity and acceptance (Zeffane, 2010). This study intends to re-affirm these findings in context to the Indian scenario.

Hence, we propose the following hypothesis:

H1: Ethical leadership has a positive correlation with employee trust on their leaders.

\section{Employee trust on their leaders and their sales performance}

It has been proven that employees' trust towards their leader leads to high responsibility standards and willingness of the employees to be responsible for the performance outcomes of their organization leading to achievement of better sales and customer service (Robinson, Sabrina, \& Sandra, 2011).

Some researchers challenge the proportion of impact employee's trust in his/her leader has on the performance of the employee (Bachmann \& Zaheer, 2006). Yet, many other research studies have shown that employees who trust their leaders, are more comfortable in risking the relationship with their leaders - by admitting mistakes or sharing sensitive information (Dirks \& Ferrin, 2002; Mayer, Davis, \& Schoorman,1995); also, they tend to respond to their leaders by doing hard work on essential tasks and giving performance beyond what is expected of them (Dirks \& Ferrin, 2002; Konovsky \& Pugh, 1994). This is an important consideration as employees who are not confident enough in trusting their leaders will spend considerable amount of time in securing their positions by documenting records of their satisfactory work which will have an impact on their overall performance (Dirks \& Ferrin, 2002; Mayer \& Gavin,2005). Thus, it is safe to conclude that a positive correlation exists between employees' trust in his/her leaders and employee performance and motivation (Dirks \& Ferrin, 2002; Konovsky \& Pugh, 1994; Gillespie \& Mann, 2004; Wong, Wong, Ngo, \& Lui, 2005). Trust is an extremely crucial factor for performance outcome as it is a prerequisite for the exchanges that are related to performance outcomes. Exchanges create inter-dependence between interacting parties and with inter-dependence, come risks into consideration. One of the risks that can possibly arise is that the person's contribution to the exchanges might not be responded back. Trust permits parties to expose themselves to such risks with the belief that favorable outcomes will be achieved (Rousseau D. M., Sitkin, Burt, \& Camerer, 1998). Thus, we propose the following hypothesis as

H2: Employee trust in their leaders has a positive correlation with their sales performance levels

Also, for confirming the role of trust as a moderator on the correlation between ethical leadership and its effect on sales performance, we propose the hypothesis as

H3: There is a significant difference between the levels of employee performance in presence and absence of trust, at same levels of ethical leadership. Thus trust acts as a mediating factor. 


\section{Research design}

This section describes the research design of the study. It includes; the sampling method, the data collection process, the questionnaire for testing the research model.

\section{Data collection}

Data was collected from respondents having past/current sales experience in a wide variety of fields. Respondents mostly belonged to the state of Maharashtra, India.

Table 1 Sample descriptive

\begin{tabular}{|c|c|c|c|c|c|c|c|}
\hline Gender & Male & Female & & & & & \\
\hline Count & 109 & 38 & & & & & \\
\hline Percentage & $74.15 \%$ & $25.85 \%$ & & & & & \\
\hline \multirow[t]{2}{*}{ Age } & $21-25$ & $26-30$ & $31-35$ & $36-40$ & $41-45$ & $\begin{array}{l}46- \\
50\end{array}$ & $51+$ \\
\hline & 50 & 47 & 18 & 9 & 12 & 7 & 4 \\
\hline \multirow[t]{2}{*}{ Education } & 12 th & Diploma & Graduation & Post-graduation & Ph.D & & \\
\hline & 2 & 1 & 47 & 94 & 3 & & \\
\hline \multirow[t]{2}{*}{$\begin{array}{l}\text { Sales position } \\
\text { in } \\
\text { organization }\end{array}$} & $\begin{array}{l}\text { Junior } \\
\text { level }\end{array}$ & $\begin{array}{l}\text { Middle } \\
\text { level }\end{array}$ & Senior level & & & & \\
\hline & 61 & 64 & 22 & & & & \\
\hline \multirow[t]{2}{*}{$\begin{array}{l}\text { Formal ethics } \\
\text { training to } \\
\text { employees } \\
\end{array}$} & Yes & No & Not aware & & & & \\
\hline & 46 & 65 & 36 & & & & \\
\hline
\end{tabular}

\section{Measures}

The measures for all the three constructs were taken from previously available literature inculcating minor changes in the wordings of items for matching the context of our research study. In order to avoid method bias to some extent, procedural remedy was adopted by measuring Ethical leadership and trust on 7 point Likert scale and measuring Sales performance on a 5-point Likert scale i.e. proximal separation was adopted as a procedural remedy in order to avoid common method biases arising out of same respondent answering questions of I.V. as well as D.V. scales (Podsakoff, MacKenzie, Lee, \& Podsakoff, 2003).

\section{Questionnaire design}

The questionnaire was designed using already published scales to reliably measure the constructs under study. Data was collected from the respondents (all having previous or current sales experience) by contacting them individually through one-to-one communication and were assured of confidentiality of data provided by them in order to address any privacy concerns.

\section{Reliability testing of the scales}

Table 2 Reliability statistics of ethical leadership, trust and sales performance scale

\begin{tabular}{|c|r|r|r|}
\hline & \multicolumn{3}{|c|}{ Reliability statistics } \\
\hline Scale & Cronbach's Alpha & Cronbach's Alpha Based on Standardized Items & N of Items \\
\hline Ethical leadership & .934 & .933 & 10 \\
\hline Trust & .974 & .973 & 20 \\
\hline Sales performance & .926 & .927 & 20 \\
\hline
\end{tabular}

For ethical leadership, trust and sales performance scale the Cronbach's alpha was very high at $0.934,0.973,0.934$ respectively showing very high levels of internal consistency of the scale.

Hence, we finalized the questionnaire design.

\section{Pre-testing and pilot testing of questionnaire}

The questionnaire was initially refined under the guidance of subject matter experts. Subsequently, a pilot was run with 20 respondents to validate the questionnaire. 


\section{Response bias control}

Social acceptability is one of the most prevalent factors affecting the acceptability of survey research findings. In order to cope up with this issue, the questionnaire was designed keeping in consideration forced choice method with the central rating value of the rating scale representing neutral choice (Nederhof, 1985). The method of sampling used for this study was convenience sampling by contacting the people in the knowledge of the researchers having sales experience.

\section{Statistical control of response bias}

Post data collection, Harman's single factor test was conducted to check the levels of method variance. A single factor accounted for less than majority $(<50 \%)$ of the covariance among all the variables. This indicates that common factor variance was not a concern in our study (Podsakoff, MacKenzie, Lee, \& Podsakoff, 2003). The output of the Harman's single factor test is as follows

Table 3 Harman's collinearity test output

\begin{tabular}{|l|r|r|r|r|r|r|}
\hline \multicolumn{7}{|c|}{ Total variance explained } \\
\hline \multirow{2}{*}{ Component } & \multicolumn{1}{|c|}{ Initial Eigen values } & \multicolumn{2}{c|}{ Extraction Sums of Squared Loadings } \\
\cline { 2 - 7 } & \multicolumn{1}{|c|}{ Total } & \% of Variance & Cumulative \% & Total & \% of Variance & Cumulative \% \\
\hline 1 & 21.664 & 43.329 & 43.329 & 21.664 & 43.329 & 43.329 \\
\hline 3 & 5.098 & 10.197 & 53.526 & & & \\
\hline
\end{tabular}

Extraction Method: Principal Component Analysis.

\section{Methodology}

The research was undertaken using correlation type investigation to explain the effect of ethical leadership on sales performance, with trust as the mediating factor in this relationship. The mean of responses for all the items of the scale was calculated to get the scale scores for all the respondents for all three variables under study (Robinson M. A., 2018).

Two models were conceptualised to be accessed separately. In the first model, we tried to find the level of correlation between ethical leadership and sales performance directly, in absence of trust as a mediating variable

Fig. 2 Model 1: Relationship between ethical leadership and sales performance

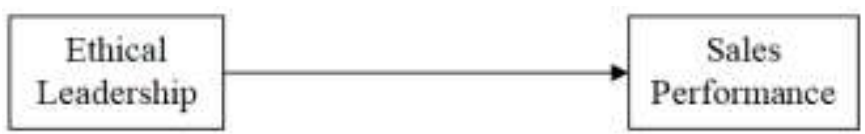

The output of correlation analysis was as follows

Table 4 Correlation table for model 1

\begin{tabular}{|l|l|r|r|}
\hline \multicolumn{9}{|c|}{ Correlations } \\
\hline \multirow{2}{*}{ Pearson Correlation } & Sales_performance & 1.000 & Ethical_Leadership \\
\cline { 2 - 5 } & Ethical_Leadership & .510 & .510 \\
\hline \multirow{2}{*}{ Sig. (1-tailed) } & Sales_performance & .000 \\
\cline { 2 - 5 } & Ethical_Leadership & .000 & .000 \\
\hline \multirow{N}{*}{$\mathrm{N}$} & Sales_performance & 147 & 147 \\
\cline { 2 - 5 } & Ethical_Leadership & 147 & 147 \\
\hline
\end{tabular}

Table 5 ANOVA table for model 1

\begin{tabular}{|l|l|r|r|r|r|r|}
\hline \multicolumn{2}{|c|}{ ANOVA $^{\mathrm{a}}$} \\
\hline Model & Sum of Squares & $\mathrm{df}$ & Mean Square & \multicolumn{1}{c|}{ F } & Sig. \\
\hline \multirow{3}{*}{1} & Regression & 10.958 & 1 & 10.958 & 50.952 & $.000^{\mathrm{b}}$ \\
\cline { 2 - 8 } & Residual & 31.186 & 145 & .215 & & \\
\cline { 2 - 8 } & Total & 42.144 & 146 & & & \\
\hline
\end{tabular}

a. Dependent Variable: Sales_performance

b. Predictors: (Constant), Ethical_Leadership

It was noted that a moderately strong correlation exists between ethical leadership and sales performance which is significant at $95 \%$ of significance. 
The regression analysis provided the following outcome

Table 6 Model summary table for model 1

Model summaryb

\begin{tabular}{l|c|c|r|r|r|}
\hline Model & $\mathrm{R}$ & R Square & Adjusted R Square & Std. Error of the Estimate & Durbin-Watson \\
\hline 1 & $.510^{\mathrm{a}}$ & .260 & .255 & .46376 & 2.099 \\
\hline
\end{tabular}
a. Predictors: (Constant), Ethical_Leadership
b. Dependent Variable: Sales_performance

From the adjusted R square values, it can be conclude that approximately $26 \%$ of sales performance of sales employees can be attributed to ethical leadership.

Table 7 Coefficients table for model 1

\begin{tabular}{|c|c|c|c|c|c|c|c|c|c|c|c|}
\hline \multicolumn{12}{|c|}{ Coefficients $^{a}$} \\
\hline \multirow{2}{*}{\multicolumn{2}{|c|}{ Model }} & \multicolumn{2}{|c|}{$\begin{array}{l}\text { Unstandardized } \\
\text { Coefficients }\end{array}$} & \multirow{2}{*}{$\begin{array}{c}\begin{array}{c}\text { Standardized } \\
\text { Coefficients }\end{array} \\
\text { Beta }\end{array}$} & \multirow[b]{2}{*}{$\mathrm{t}$} & \multirow[b]{2}{*}{ Sig. } & \multicolumn{3}{|c|}{ Correlations } & \multicolumn{2}{|c|}{$\begin{array}{c}\text { Collinearity } \\
\text { Statistics }\end{array}$} \\
\hline & & $\mathrm{B}$ & $\begin{array}{l}\text { Std. } \\
\text { Error }\end{array}$ & & & & $\begin{array}{l}\text { Zero- } \\
\text { order }\end{array}$ & Partial & Part & $\begin{array}{c}\text { Toleranc } \\
\mathrm{e}\end{array}$ & VIF \\
\hline 1 & (Constant) & 2.930 & .178 & & 16.488 & .000 & & & & & \\
\hline & $\begin{array}{l}\text { Ethical_Leaders } \\
\text { hip }\end{array}$ & .230 & .032 & .510 & 7.138 & .000 & .510 & .510 & .510 & 1.000 & 1.000 \\
\hline
\end{tabular}

a. Dependent Variable: Sales_performance

The beta value of 0.51 was obtained and VIF value of 1.000 was obtained, confirming the absence of multi-collinearity in the data.

For checking the effects of mediation of trust on the relation of ethical leadership with sales performance, the second model is proposed as

Fig. 3 Model 2: Relationship between ethical leadership and sales performance mediated by trust

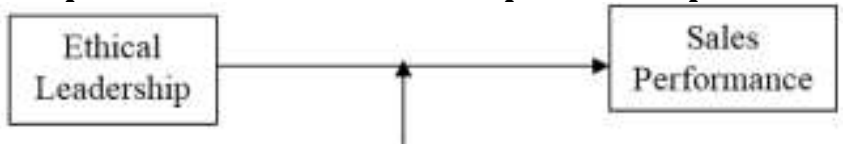

Trust

The correlation analysis was done using ethical leadership and trust as independent variables. Sales performance was taken as the dependent variable. The output was as follows:

Table 8 Correlations table for model 2

\begin{tabular}{|c|c|c|c|c|}
\hline \multicolumn{5}{|c|}{ Correlations } \\
\hline & & Sales_performance & Ethical_Leadership & Trust \\
\hline \multirow[t]{3}{*}{ Pearson Correlation } & Sales_performance & 1.000 & .510 & .539 \\
\hline & Ethical_Leadership & .510 & 1.000 & .801 \\
\hline & Trust & .539 & .801 & 1.000 \\
\hline \multirow[t]{3}{*}{ Sig. (1-tailed) } & Sales_performance & & .000 & .000 \\
\hline & Ethical_Leadership & .000 & & .000 \\
\hline & Trust & .000 & .000 & \\
\hline \multirow[t]{3}{*}{$\mathrm{N}$} & Sales_performance & 147 & 147 & 147 \\
\hline & Ethical_Leadership & 147 & 147 & 147 \\
\hline & Trust & 147 & 147 & 147 \\
\hline
\end{tabular}

It is seen that the correlation of sales performance with trust is 0.539 and that of ethical leadership with trust is 0.801 and are significant.

Table 9 Model summary table for model 2 Model summaryb

\begin{tabular}{|l|c|r|r|r|r|}
\hline \multicolumn{7}{|c|}{ Model summary $^{\mathbf{b}}$} \\
\hline Model & $\mathrm{R}$ & R Square & Adjusted R Square & Std. Error of the Estimate & Durbin-Watson \\
\hline 1 & $.555^{\mathrm{a}}$ & .308 & .298 & .45006 & 2.099 \\
\hline
\end{tabular}

a. Predictors: (Constant), Trust, Ethical_Leadership

b. Dependent Variable: Sales_performance 
Again, from the adjusted $\mathrm{R}$ square values, it can be concluded that approximately $30 \%$ of sales performance of sales employees can be attributed to ethical leadership when mediated by trust. This has improved by $4 \%$ over the model where trust was not considered as the mediating factor.

Table 10 ANOVA table for model 2

\begin{tabular}{|l|l|r|r|r|r|r|}
\hline \multicolumn{7}{|c|}{ ANOVA } \\
\hline Model & Sum of Squares & df & Mean Square & F & Sig. \\
\hline \multirow{3}{*}{1} & Regression & 12.976 & 2 & 6.488 & 32.032 & $.000^{\mathrm{b}}$ \\
\cline { 2 - 7 } & Residual & 29.168 & 144 & .203 & & \\
\cline { 2 - 7 } & Total & 42.144 & 146 & & & \\
\hline
\end{tabular}

a. Dependent Variable: Sales_performance

b. Predictors: (Constant), Trust, Ethical_Leadership

Table 11 Coefficients table for model 2

\begin{tabular}{|c|c|c|c|c|c|c|c|c|c|c|c|}
\hline \multicolumn{12}{|c|}{ Coefficients $^{a}$} \\
\hline \multirow{2}{*}{\multicolumn{2}{|c|}{ Model }} & \multicolumn{2}{|c|}{$\begin{array}{l}\text { Unstandardize } \\
\text { d Coefficients }\end{array}$} & \multirow{2}{*}{$\begin{array}{c}\begin{array}{c}\text { Standardized } \\
\text { Coefficients }\end{array} \\
\text { Beta } \\
\end{array}$} & \multirow[b]{2}{*}{$\mathrm{t}$} & \multirow[b]{2}{*}{ Sig. } & \multicolumn{3}{|c|}{ Correlations } & \multicolumn{2}{|c|}{$\begin{array}{c}\text { Collinearity } \\
\text { Statistics }\end{array}$} \\
\hline & & $\mathrm{B}$ & $\begin{array}{c}\text { Std. } \\
\text { Error }\end{array}$ & & & & $\begin{array}{l}\text { Zero- } \\
\text { order }\end{array}$ & Partial & Part & Tolerance & VIF \\
\hline \multirow[t]{3}{*}{1} & (Constant) & 2.766 & .180 & & 15.356 & .000 & & & & & \\
\hline & $\begin{array}{l}\text { Ethical_Lea } \\
\text { dership }\end{array}$ & .098 & .052 & .217 & 1.878 & .062 & .510 & .155 & .130 & .359 & 2.787 \\
\hline & Trust & .164 & .052 & .365 & 3.156 & .002 & .539 & .254 & .219 & .359 & 2.787 \\
\hline
\end{tabular}

a. Dependent Variable: Sales_performance

It can be seen that the beta value of ethical leadership has reduced substantially and is no longer significant after the addition of trust variable in the model. Trust now has a significant beta value.

Also, the VIF values are 2.787 which are below the generally accepted limit of 3 which re-affirms the absence of multi-collinearity from the data.

\section{Conclusion}

It can be concluded through the study that a positive correlation exists between ethical leadership and sales performance of employees, as shown by model 1. This proves our hypothesis H1 i.e.: Ethical leadership has a positive correlation with employee trust on their leaders.

Also, as seen from the output of model 2, a strong positive correlation is found to exist between the level of trust of employees on their leaders and their sales performance. This proves our hypothesis H2 i.e.: Employee trust in their leaders has a positive correlation with their sales performance levels. By comparing the changes in the beta values of variables in model 1 and model 2, we can say that trust is a mediating factor between ethical leadership and sales performance. This proves our proposed hypothesis H3 i.e.: There is a significant difference between the levels of employee performance in presence and absence of trust, at same levels of ethical leadership. Thus, trust acts as a mediating factor.

\section{Future studies and limitations}

This study has focused on only one of the many antecedents to sales performance where others are also equally important. Separate study can be undertaken to analyse the effect of each of these antecedents to sales performance. Also, only one intermediating variable viz. trust was taken into consideration for this study but many other factors such as amount of training deployed, IQ level of the employee, education level, etc. can be considered as mediating variables for future study. Also, studies can be conducted to confirm the regional validity of the output of this research as most respondents belonged to the state of Maharashtra, India. Also, responses from women were comparatively lower than that of the male respondents as the ratio of women is lower in comparison in the sales domain. Industry specific studies can also be carried out to compare the degree to which the effect of ethical leadership on sales performance varies across sectors. Apart from this, studies can be conducted to confirm the validity of the results of this study across urban and rural population of sales employees.

\section{References}

1. Adams (2008). Trust in Teams Scale; Trust in Leaders Scale; Manual for administration and analyses. Toronto: Department of national defence, Canada.

2. Anderson, E., \& Oliver, R. L. (1987). Perspectives on behavior-based versus outcome-based salesforce control systems. Journal of Marketing , 51(4), 76-88.

3. Armstrong, A., \& Francis, R. (2008). An Ethical Climate is a Duty of Care. Journal of Business Systems, Governance and Ethics , Vol3, No.3,16. 
4. Aronson. (2001). Integrating Leadership Styles and Ethical Perspectives. Canadian Journal of Administrative Sciences , 18,244-256.

5. Bachmann, R., \& Akbar, Z. (2006). Handbook of Trust Research. Northampton, MA: Edward Elgar Publishing.

6. Baldauf, A., Cravens, D. W., \& Grant, K. (2002). Consequences of sales management control in field sales organizations: a cross national perspective. International Business Review , 11, 577-609.

7. Bandura. (2003). Negative self-efficacy and goal effects revisited. Journal of applied psychology, 88(1),87-99.

8. Bartkus, Kenneth, R., Peterson, M. F., \& Danny, B. N. (1989). Type A Behavior, Experience, and Salesperson Performance. Journal of Personal Selling and sales management, 11-18.

9. Bedi, A., Alpaslan, C. M., \& Green, S. (2016). A Meta-analytic Review of Ethical Leadership Outcomes and Moderators. Journal of Business Ethics , 517-536.

10. Behrman, Perrault, W. D., \& Douglas, N. (1984). A Role Stress Model of the Performance and Satisfaction of Industrial Salespersons. Journal of marketing, 9-21.

11. Bishop, W. H. (2013). The role of ethics in 21st century organizations. Journal of Business Ethics, 118, 635-637.

12. Brown, Linda, K. T., \& David, A. H. (2005). Ethical leadership: A social learning perspective for construct development and testing. Organizational Behaviour and Human Decision Processes, 97,117-134.

13. Brown, S. P., Cron, W., \& Slocum, J. W. (1998). Effects of trait competitiveness and perceived intraorganizational competition on salesperson goal setting and performance. Journal of Masrketing , 61(1),39-50.

14. Chakrabarti, D., Bradley, B. R., Leyland, P., Pierre , B., \& Lien, M. L. (2014). Goal orientation effects on behavior and performance: Evidence from International Sales Agents in the Middle East. International Journal of Human Resource Management, 317-340.

15. Chen, A. S., \& Hou, Y. (2016). The effects of ethical leadership, voice behavior and climates for innovation on creativity:A moderated mediation examination. The Leadership Quarterly, 27(1), 1-13.

16. Churchill, G. A., Ford, N. M., Hartley, S. W., \& Walker. (1985). The determinants of salesperson performance: A metaanalysis. Journal of Marketing Research ,22(2), 103-118.

17. Churchill, Gilbert, A., Ford, N. M., \& Walker, O. C. (1976). Organizational Climate and Job Satisfaction in the Salesforce. Journal of Marketing research, 323-332.

18. Churchill, Gilbert, A., Ford, N. M., Hartley, S. W., \& Walker, O. C. (1985). The Determinants of Salesperson Performance: A Meta-analysis. Journal of Marketing Research , 103-18.

19. Cook, J., \& Wall, T. (1980). New Work Att itude Measures of Trust, Organizational Commitment and Personal Need NonFulfi llment. Journal of Occupational and Organizational Psychology, vol. 53, no. 1, pp. 39-52.

20. Cravens, D. W., Piercy, N. F., \& Low, G. S. (2006). Globalization of the Sales Organization: Management Control and Its Consequences. Organizational Dynamics , 35, 3,291-303.

21. Dellagi, A. (2015). The Relationship Between Role Overload, Depresonalization and Commercial Performance. European Journal of Business and Social Sciences, Vol4,189-193.

22. Dirks, K., \& Ferrin, D. (2002). Trust in Leadership: Meta-Analytic Findings and Implications for Research and Practice. Journal of Applied Psychology, vol. 87, no. 4, pp. 611-628.

23. Dragnić, D. (2014). Impact of Internal and external factors on the performance of fast-growing small and medium businesses. Journal of Contemporary Management Issues, 119-159.

24. Driscoll, J. W. (1978). Trust and Participation in Organizational Decision Making as Predictors of Satisfaction. Academy of Management Journal , 21(1), 44-56.

25. Dwyer, F., \& Lagace, R. (1986). On the Nature and Role of Buyer-Seller Trust. AMA Educators Conference Proceedings, Chicago: American Marketing Association , 40-45.

26. Emmanuel, E. Y. (2013). Factors Affecting the Performance of Sales Personnel of Insurance Companies in Ghana. Kuwait chapter of rabian Journal of Business and Management Review , 73-79.

27. Fatima, \& Zoha. (2018). Impact of Sales Territory Design and Salesforce Performance on Sales Organization Effectiveness: A Review of Studies. Amity Global Business Review , 46-47.

28. Fish, M., Wittmann, M. C., \& Arnett, D. B. (1989). Summary Brief Salesperson Performance: The Effect of Salesperson Identity Salience, Commitment to Supervisor, and Job Satisfaction.

29. Flaherty, K. E., Mowen, J. E., Brown, T. J., \& Marshall, G. W. (2009). Leadership Propensity and Sales Performance among Sales Personnel and Managers in a Specialty Retail Store Setting. The Journal of Personal Selling and Sales Management , 43-59.

30. Francis, R. D. (2000). Ethics and Corporate Governance: An Australian Handbook. Sydney: University of New South Wales.

31. Gillespie, N., \& Mann, L. (2004). Transformational Leadership and Shared Values: The Building Blocks of Trust. Journal of Managerial Psychology, vol. 19, no. 6, pp. 588-607.

32. Gregory, \& Rich, A. (1997). The Sales Manager as a Role Model: Effects on Trust, Job Satisfaction, and Performance of Salespeople. Journal of the academy of marketing science, 319.

33. Hafeez, \& Amna Hasnain. (2012). Relationship of leadership styles, employees commitment and organization performance (A study on customer support representatives). European Journal of Economics, Finance and Administrative Sciences , 134

34. Humphreys. (2002). Transformational leader behaviour, proximity and successful services marketing. Journal of services markting , 16,6,487-502.

35. Ingram, Schwepker, \& Hutson. (1992). Why sales people fail. Industrial marketing management, 21,225-230.

36. Ingram, Thomas, \& Bellenger, D. N. (1983). Personal and Organizational Variables: Their Relative Effect on Reward Valences of Industrial Salespeople. Journal of Marketing Research , 198-205.

37. Jackson, L. (2014). The Work Engagement and Job PerformanceRelationship: Exploring the Mediating Effect ofTrait Emotional Intelligence. San Jose State University.

38. Juneja, P. Leadership Ethics - Traits of an Ethical Leader. Management Study Guide Content Team. 
39. Kanungo. (2001). Ethical Values of Transactional and Transformational Leaders. Canadian Journal of Administrative Sciences , 18,257-265.

40. Kerr, S., \& Jermier, J. M. (1978). Substitutes for Leadership: Their Meaning and Measurement. Organizational behavior and human Performance, 22, 375- 403.

41. Konovsky, M. A., \& Pugh, S. D. (1994). Citizenship Behavior and Social Exchange. Academy of Management Journal, vol. 37, no. 3, pp. 656-669.

42. Kukic, S., Bandur, K., Bevanda, M., Bijaškić Martinović, Čutura, M., Lelčić, S., et al. (2007). Marketing, Sveučilište u Mostaru. Ekonomski Fakultet Mostar.

43. Locke. (2002). Building a practically useful theory of goal setting and task-motivation; a 35-year odyssey. American Psychologist, 57(9),707-717.55.

44. Luhmann, N. (1982). Trust and Power. New York, NY: John Wiley \& Sons.

45. Luthans. (2002). Employee engagement and manager self-efficacy. Journal of management development.

46. Mayer, R. C., \& Gavin, M. B. (2005). Trust in Management and Performance: Who Minds the Shop while the Employees Watch the Boss? Academy of Management Journal, vol.48, no. 5, pp. 874-888.

47. Mayer, R. C., Davis, J. H., \& Schoorman, F. D. (1995). An Integrative Model of Organizational Trust. Academy of Management Review , pp. 709-734.

48. Mayer, R. D. (1995). An Integrative Model of Organizational Trust. Academy of Management Review , vol. 20, no. 3, pp. 709-734.

49. McIntyre, R. P., Claxton, R. P., Anselmi, K., \& Wheatley, E. W. (2000). cognitive style as an antecedent to adaptiveness, customer orientation, and self-perceived selling performance. Journal of Business and Psychology, 179-196.

50. McIntyre, R. P., Claxton, R. P., Anselmi, K., \& Wheatley, E. W. (2010). The relationship between sales skills and salesperson performance : an empirical study in the Malaysia telecommunications company. International Journal of Management and marketing research. , 51-68.

51. Nederhof, A. J. (1985). Methods of Coping With Social Desirability Bias: A Review. European journal of social psychology, 15(3):263 - 280.

52. Nema, G., \& Sethia, G. (2015). A comparative study of the factors affecting salesforce performance in urban and rural areas. Abhinav International Monthly Refereed Journal of Research in Management and Technology, 41-46.

53. O'hara, Brandley, S., Boles, j. S., \& Johston, M. W. (1991). The Influence of Personal Variables on Salesperson Selling Orientation. Journal of personal Selling \& Sales Management, 62-67.

54. Onyemah, V. (2008). Role ambiguity, role conflict and performance: Empirical evidence of an inverted-U relaitonship. Journal of personal selling and sales management, 28(3):299-314.

55. Paine, L. S. (1994). Managing for Organizational Integrity. Harvard Business Review, 106-117.

56. Piercy, Low, G. S., \& Cravens, D. W. (2011). Country differences concerning sales organization and salesperson antecedents of sales unit effectiveness. Journal of World Business, 46, 104-115.

57. Piercy, N. F., \& Lane, N. (2005). Strategic imperatives for transformation in the conventional sales organization. Journal of Change Management $5,249-266$.

58. Podsakoff, P. M., MacKenzie, S. B., \& Lee, J.-Y. (2003). Common Method Biases in Behavioral Research: A Critical Review of the Literature and Recommended Remedies. Journal of Applied Psychology, Vol. 88, No. 5, 879-903.

59. Podsakoff, P. M., MacKenzie, S. B., Lee, J.-Y., \& Podsakoff, N. P. (2003). Common Method Biases in Behavioral Research: A Critical Review of the Literature and Recommended Remedies. Journal of Applied Psychology, Vol. 88, No. 5, 879-903.

60. Rahim, M. A., \& Salleh, K. (2010). Ethical Leadership and Employee Trust: Governance Perspective. Information and Financial Engineering (ICIFE) (pp. 848-851). Malaysia: IEEE International.

61. Robinson, M. A. (2018). Using multi-item psychometric scales for research and practice in human resource management. Human Resource Management, Wiley periodicals, 57:739-750.

62. Robinson, Sabrina, D. S., \& Sandra, L. (2011). Trust that binds: The impact of collective felt trust on organizational performance. The University of British Columbia.

63. Rotter, J. (1967). New Scale for the Measurement of Interpersonal Trust. Journal of Personality, 35(4), 651-665.

64. Rousseau, D. M., Sitkin, S. B., Burt, R. S., \& Camerer, C. (1998). Not So Diff erent After All: A Cross Discipline View of Trust. Academy of Management Review , vol. 23, no. 3, pp.393-404.

65. Rousseau, D. M., Sitkin, S. B., Burt, R. S., \& Camerer, C. (1998). Not so different after all: A cross-discipline view of trust. Academy of Management Review , 23, 393-404.

66. Sarwar, F., \& Hasan, S. (2015). Impact of Expectancy Based Dispositional Traits of Self Efficacy and Optimism on Job Satisfaction among University Faculty Members: Mediating Role of Affective Organizational Commitment. Research on Humanities and Social Sciences, Vol4,53-61.

67. Schurr, P. H., \& Ozanne, J. L. (1985). Influences on Exchange Partners Processes: Buyers' Preconceptions of a Seller's Trustworthiness and Bargaining Toughness. Journal of Consumer Research , 11(4),939-953.

68. Shaw, R. (1997). Trust in the Balance: Building Successful Organizations on Results, Integrity, and Concern. San Francisco: Jossey-Bass.

69. Singh, Koshy, \& Ramendra. (2010). Determinants of B2B salesperson performance and effectiveness, a review and synthesis of literature. Journal of business and industrial marketing , 25/7,535-546.

70. Steven, P., \& Peterson, R. A. (1994). The Effect of Effort on Sales Performance and Job satisfaction. Journal of Marketing , 70-80.

71. Suhonen, R., Stolt, M., Virtanen, H., \& Leino-Kilpi, H. (2011). Organizational ethics: A literature review. Nursing Ethics , $18,285-303$.

72. T. C. (2001). The Ethical leader. Executive Excellence, 31-40.

73. Trevino, I. K. (2003). A qualitiative investigation of perceived executive ethical leadership; perceptions from inside and outside the executive suite. Human relations, 56,5-37.

74. Verbeke, W., Dietz, B., \& Verwaal, E. (2010). Drivers of sales performance: A contemporary meta-analysis. Journal of the academy of marketing science, 39(3):407-428. 
75. Wali, R. u., Saqib, Y., \& Hummayoun , N. (2015). Impact of burnout on employees' performance: An analysis of banking industry. World Review of Entrepreneurship Management and Sustainable Development .

76. Walker, Orville , C. J., Gilbert, C. A., \& Ford, N. M. (1977). Motivation and Performance in Industrial Selling: Present Knowledge and Needed Research. Journal of Marketing Research, 156-168.

77. Walker, Orville, C. J., Churchill, G. A., \& ford, N. M. (1975). Organizational Determinants of the Industrial Salesmen's Role Conflict and ambiguity. Journal of marketing , 32-39.

78. Wang, G. (2000). Personal Factors Affecting Sales Performance: Modeling the Effects of Experience,Competitiveness, Self -Efficacy, Effort, and Creativity. LSU Historical Dissertations and Theses, No page number.

79. Wong, Y. T., Wong, C. S., Ngo, H. Y., \& Lui, H. K. (2005). Different responses to job insecurity of Chinese workers in joint ventures and state-owned enterprises. Human Relations , 58, 1391-1418.

80. Zeffane, $R$. (2010). Towards a two-factor theory of interpersonal trust: A focus on trust in leadership. International Journal of Commerce and Management, 20(3),246-257. 